\section{LA HORA DEL RELEVO}

\section{J.A. Carballido Rodriguez}

Profesor Titular de Urología U.A.M.
$E$ l comienzo del nuevo año 2004 marca una nueva etapa de ACTAS UROLÓGICAS ESPAÑOLAS que se refleja en un cambio importante, el reglamentario de la renovación en su Dirección, ajustándose a los Estatutos y Reglamento de la Asociación Española de Urología (A.E.U.).

La prolongada y activa dedicación personal a ACTAS UROLÓGICAS ESPAÑOLAS en los últimos años culmina con una oportuna renovación tras una larga trayectoria contemplada sucesivamente desde el Comité de Redacción, la Secretaría de Redacción y en los últimos ocho años la Dirección.

A lo largo de estas etapas en repetidas Editoriales ${ }^{1-3}$ y en los Informes Anuales a la Asamblea Plenaria de la A.E.U. he justificado y destacado los aspectos más relevantes de la evolución de ACTAS UROLÓGICAS ESPAÑOLAS. Todos ellos, han matizado y definido no sólo su creciente contenido científico en el ámbito de las publicaciones en Urología sino también su formato editorial y la labor informativa de actividades nacionales e internaciones de interés urológico dando respuesta a su carácter de Órgano de Difusión de nuestra Asociación.

La posición actual de ACTAS UROLÓGICAS ESPAÑOLAS en el contexto Editorial de las Revistas Científicas en Biomedicina es de reconocido prestigio en el marco de las publicaciones en Urología y lengua española; la presencia y selección en el Índice Bibliográfico Español de Ciencias de la Salud (IBECS), en el Scientific Electronic Library on Line (SCIELO), el acuerdo de colaboración para publicación paralela de artículos seleccionados con el European Urology y la Edición en Internet son logros recientes y significativos ${ }^{2-3}$.

El protagonismo en el momento de la despedida no me corresponde, sin embargo, es el momento oportuno para destacar que los logros alcanzados a lo largo de estos años deben repartirse entre los sucesivos equipos de profesionales y miembros de Comités que han ocupado y ocupan con profesionalidad estos cargos.

Ahora, la responsabilidad de la Dirección se ha confiado al Dr. José Luis Ruiz Cerdá, por decisión de los Órganos de Dirección de la A.E.U.; sus iniciativas y las aportadas por el Equipo que el incorpore conducirán el nuevo camino de ACTAS UROLÓGICAS ESPAÑOLAS. 
Los retos están identificados y planteados en reflexiones Editoriales recientes; incrementar la calidad y rigor científico de los contenidos, conseguir mayor número de citaciones para mejorar el factor de impacto inicial y adaptarse a las nuevas tecnologías que se incorporan a las publicaciones biomédicas (lengua inglesa, check-lists de evaluación etc...) constituyen objetivos razonables ${ }^{1-3}$.

Superar con eficacia los retos ya planteados y los que surjan en un futuro, es lo que deseamos para esta nueva etapa de ACTAS UROLÓGICAS ESPAÑOLAS.

\section{REFERENCIAS}

1. CARBALLIDO RODRÍGUEZ, J.A.: Gratitud y desafios (nuevos retos). Actas Urol Esp 2000; 24 (6): 444-445.

2. CARBALLIDO RODRÍGUEZ, J.A.: Reflexiones editoriales sobre las publicaciones en español. Actas Urol Esp 2001; 25 (9): 606-609.

3. CARBALLIDO RODRÍGUEZ, J.A.: Índice Bibliográfico Español de Ciencias de la Salud (IBECS) y ACTAS UROLÓGICAS ESPAÑOLAS: Actas Urol Esp 2002; 26 (6): 381-383. 


\section{J.L. Ruiz Cerdá}

Director de Actas Urológicas Españolas
$E$ n este momento en el que inicio esta nueva andadura como director de Actas Urológicas Españolas quisiera expresar mis sentimientos de reconocimiento, responsabilidad y agradecimiento. Reconocimiento a la labor llevada a cabo por los anteriores directores de la revista. Su contribución ha sido decisiva. Al doctor Alférez por su impulso inicial, tan necesario e imprescindible cuando algo nace. Al doctor Leiva por conseguir estabilizar y consolidar la revista. Por último, y muy especialmente, al doctor Carballido por aumentar su nivel científico y dejarla en una posición de ventaja con respecto a otras publicaciones de habla hispana. En los últimos 8 años como director, ha conseguido que Actas evolucione extraordinariamente. La labor que ha realizado ha sido muy relevante. En el terreno de la edición, se ha conseguido una revista con personalidad propia. Dispone de un diseño cuidado y un formato uniforme con secciones estables y consolidadas. Su comité de redacción ha sido renovado recientemente. La inclusión de nuevos miembros ha logrado combinar experiencia y vigor. En cuanto a su contenido, el avance ha sido evidente. No sólo por las nuevas secciones como, por ejemplo, imágenes en urología, sino por el aumento en la calidad metodológica y en la exposición de resultados de los trabajos publicados. Este último hecho es reflejo del elevado nivel científico de la urología española, pero también, de la labor llevada a cabo por el consejo asesor y redactor de la revista. Por otra parte, se ha aumentado el número y la cuantía económica de los premios que anualmente otorga la revista. Además, la remisión de originales en soporte informatizado está plenamente consolidada. Otros logros conseguidos han sido, el acuerdo con los editores del European Urology para publicar los mejores trabajos de Actas y la inclusión de la revista en el registro de SCIELO. Estos son algunos ejemplos, aunque se podrían citar muchos más.

El sentimiento de responsabilidad es obvio. En primer lugar, porque en las páginas de Actas ha quedado reflejada la historia de la urología española. En ellas se recoge el esfuerzo profesional y personal de muchos urólogos durante los últimos 27 años. Todas las aportaciones han sido válidas. Desde el residente que publicó una nota clínica, hasta el urólogo experto que expresó su prestigiosa opinión en un editorial. Desde el urólogo que publicó su experiencia clínica, fruto del trabajo en un pequeño hospital, hasta aquel que lo hizo resultado de un ensayo clínico realizado en un gran hospital terciario. Desde el flamante doctor que quiso publicar los resultados de su tesis para hacernos participe de su modesta aportación científica, hasta aquellos grupos de investigación multidisciplinarios de hospitales con grandes recursos que llevaron el proyecto más actual y puntero. Todo este esfuerzo me responsabiliza y compromete a seguir manteniendo el nivel alcanzado.

Pero, a la vez, la responsabilidad se centra en los retos del futuro. Siempre siendo conscientes de nuestra situación de partida por ser una revista en lengua hispana, tenemos que seguir mejorando y adaptarnos a la situación de la literatura científica actual. La revista debe combinar su función como órgano de difusión pero, a la vez, debe ser una 
herramienta científica útil y práctica. Tiene que satisfacer todas las inquietudes, desde la más elevada a la más modesta. El factor de impacto de la revista actual se ha estimado recientemente en 0.22 , con un nivel de inmediatez de 0.006. Este valor nos sirve como referencia de base y nuestro objetivo es mejorarlo. Sin embargo, la revista no está registrada en el Journal Citation Index, por lo que nuestra intención es incluirla en un futuro. De esta forma, todos los urólogos podrán consultarlo fácilmente. Evidentemente, este es un objetivo dificil de alcanzar. Otro objetivo deseable sería el consolidarse como la primera revista de habla hispana en urología. Para ello, se debería potenciar las relaciones con los países de lengua hispana. En esta misma dirección, sería conveniente realizar un acercamiento, unificación e integración con otras publicaciones nacionales que hacen competencia a la revista, sin complejos y con propuestas concretas. Son muchas las ideas y ganas de llevarlas a cabo. Se que cuento con el apoyo y la libertad de acción que la junta, con nuestro presidente al frente, me han proporcionado. Sólo espero, modestamente, cumplir con esta responsabilidad para que sigamos sintiéndonos orgullosos de nuestra revista.

No puedo finalizar sin expresar mi agradecimiento a todas aquellas personas que me han apoyado profesional y humanamente para alcanzar este cargo. En primer lugar, a todos los miembros de la Junta Directiva de la Asociación Española de Urología por haber depositado en mi su confianza. A lo largo de mi carrera he tenido la oportunidad de establecer vínculos profesionales con todos ellos. Mi reconocimiento profesional ha estado siempre presente, puesto que han sido referentes para mí. Sin embargo, en esta oportunidad, quisiera resaltar mi admiración por cada una de las persona de forma individual. No puedo, ni debo ocultar, mi estrecha relación con los doctores Eduardo Martínez Agulló y David Castro. Al primero, le agradezco su amistad incondicional y el haber confiado en mí desde el primer año de residente. Al segundo, le agradezco su compromiso y apoyo personal a mi trayectoria profesional. Deseo agradecer a ENE ediciones su disponibilidad y compromiso demostrados para mejorar la revista. A Joaquin Carballido por facilitarme extraordinariamente la tarea del relevo. También quisiera hacer público el agradecimiento a mis compañeros de trabajo en el servicio de urología del Hospital Universitario La Fe. En especial, a mi jefe y maestro el doctor Fernando Jiménez Cruz. Esta nueva responsabilidad es consecuencia de su influjo y de mi admiración a su persona. 